\title{
Carbonates: eco-friendly solvents for palladium-catalysed direct arylation of heteroaromatics $\dagger$
}

\author{
Jia Jia Dong, ${ }^{a}$ Julien Roger, ${ }^{a}$ Cécile Verrier, ${ }^{b}$ Thibaut Martin, ${ }^{b}$ Ronan Le Goff, ${ }^{a}$ Christophe Hoarau ${ }^{* b}$ and \\ Henri Doucet*a
}

\author{
Received 18th June 2010, Accepted 22nd September 2010 \\ DOI: $10.1039 / \operatorname{cogc00229a}$
}

The palladium-catalysed direct 2-, 4- or 5-arylation of a wide range of heteroaromatics with aryl halides proceed in moderate to good yields using the eco-friendly solvents carbonates. The best yields were obtained using benzoxazole or thiazole derivatives. The arylation of furan, thiophene, pyrrole, imidazole or isoxazole derivatives was found to require a more elevated reaction temperature.

The direct arylation of heteroaromatics is an important field for research in organic synthesis due to the biological or physical properties of the aryl-heteroaryl derivatives. ${ }^{1}$ Ohta and coworkers reported in 1985-1992 that the direct 2- or 5-arylation of several heteroaromatics with aryl halides proceed in moderate to good yields using $\mathrm{Pd}\left(\mathrm{PPh}_{3}\right)_{4}$ as the catalyst and DMAc as the solvent. ${ }^{2}$ Since these exciting results, the palladium-catalysed direct arylation of heteroaryl derivatives with aryl halides or triflates has proved to be a very powerful method for the synthesis of a wide variety of arylated heterocycles. ${ }^{3-10}$ This reaction provides a cost-effective and environmentally attractive access for the preparation of such compounds. Indeed, the major by-products of the reaction are a base associated to $\mathrm{HX}$, instead of metallic salts produced under classical crosscoupling procedures such as Suzuki, Negishi or Stille reactions. Moreover, the method avoids the preliminary preparation of a requisite organometallic reducing then the number of steps to prepare these compounds. However, these reactions were currently performed in most cases using relatively toxic solvents such as DMF, DMAc, NMP or dioxane. A few palladiumcatalysed direct arylations of heteroaromatics have also been performed using toluene, xylene or mesitylene. ${ }^{3}$ The direct arylation of oxazoles, thiazoles or indazoles using water ${ }^{11}$ as the solvent has been reported by Greaney. René and Fagnou have developed biphasic conditions using a mixture of water and EtOAc for the direct arylation of thiophenes. ${ }^{12}$ Recently, polyethylene glycol (PEG 20000) has been found to be a useful solvent for the direct arylation of triazoles. ${ }^{13}$

Carbonates, such as diethylcarbonate or propylene carbonate, are polar, aprotic, nontoxic, and biodegradable solvents. ${ }^{14}$ Based on these properties, such carbonates should offer an environ-

"Institut Sciences Chimiques de Rennes, UMR 6226 CNRS-Université de Rennes 1 "Catalyse et Organometalliques", Campus de Beaulieu, 35042, Rennes, France.E-mail: henri.doucet@univ-rennes1.fr; Fax: +33 0223236939; Tel: +33 0223236384

${ }^{b}$ Institut de Chimie Organique Fine (IRCOF) associée au CNRS (UMR 6014), INSA et Université de Rouen, BP08 76131, Mont Saint Aignan, France.E-mail: christophe.hoarau@insa-rouen.fr; Fax: +33 0235522962; Tel: +33 0235522401

$\dagger$ Electronic supplementary information (ESI) available: NMR data of new compounds. See DOI: 10.1039/c0gc00229a mentally friendly alternative to standard polar solvents. Since a few years ago, carbonates have been employed successfully for some classical metal-catalysed reactions such as enantioselective hydrogenation, alkene metathesis, carbonylation, oxidation, hydroxylation, Sonogashira coupling, Heck vinylation or allylic alkylation. ${ }^{15}$ The ruthenium-catalysed direct arylation of 2arylpyridines has also been reported recently by Fischmeister, Dixneuf and co-workers. ${ }^{16}$ However, to our knowledge, so far, carbonates have not been employed as the solvents for palladium-catalysed direct arylations. ${ }^{17}$ The use of this family of solvent would provide a cost-effective and environmentally attractive procedure for the preparation of arylated heteroarenes. Herein, we wish to report on the use of diethylcarbonate and propylene carbonate for palladium-catalysed direct 2-, or 5arylation of a wide range of heteroaromatic derivatives.

In order to determine the suitability of these solvents for palladium-catalysed direct arylations, a first set of direct arylation reactions of several heteroarenes with 4bromoacetophenone was carried out under previously reported reaction conditions but using diethylcarbonate as the solvent. ${ }^{4 h, 5 f, 6 e, 9 e}$ Employing the 2-n-butylthiophene, 2-nbutylfuran or 2-formyl- $N$-methylpyrrole and 4-bromoacetophenone as coupling partners, at $130{ }^{\circ} \mathrm{C}$ during $17 \mathrm{~h}$, the corresponding 5-arylation products were obtained in low yields. On the other hand, at this temperature, the direct arylation of benzoxazole proceeded nicely using only $1 \mathrm{~mol} \%$ of $\operatorname{PdCl}\left(\mathrm{C}_{3} \mathrm{H}_{5}\right)(\mathrm{dppb})$ as the catalyst to provide $\mathbf{1}$ in $85 \%$ isolated yield (Scheme 1, Table 1, entries 1 and 2). Interestingly, this latter reaction performed in diethylcarbonate was found to be more selective than in DMF, ${ }^{\mathrm{e}}$ DMAc, NMP or dioxane since using this solvent, fewer traces of unidentified side-products were detected (Table 1, entries 3-6).

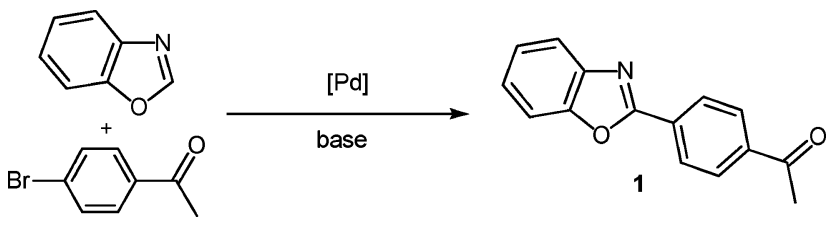

Scheme 1 Coupling of benzoxazole with 4-bromoacetophenone. 
Table 1 Influence of the reaction conditions for palladium catalysed direct coupling of benzoxazole with 4-bromoacetophenone (Scheme 1)

\begin{tabular}{llll}
\hline Entry & Catalyst & Solvent & Conversion $(\%)^{a}$ \\
\hline 1 & $\mathrm{Pd}(\mathrm{OAc})_{2}$ & diethylcarbonate & 11 \\
2 & $\mathrm{PdCl}\left(\mathrm{C}_{3} \mathrm{H}_{5}\right)(\mathrm{dppb})$ & diethylcarbonate & $91(85)$ \\
3 & $\mathrm{PdCl}\left(\mathrm{C}_{3} \mathrm{H}_{5}\right)(\mathrm{dppb})$ & DMF & $(78)^{b}$ \\
4 & $\mathrm{PdCl}\left(\mathrm{C}_{3} \mathrm{H}_{5}\right)(\mathrm{dppb})$ & DMAc & 31 \\
5 & $\mathrm{PdCl}\left(\mathrm{C}_{3} \mathrm{H}_{5}\right)(\mathrm{dppb})$ & NMP & $79(51)$ \\
6 & $\mathrm{PdCl}\left(\mathrm{C}_{3} \mathrm{H}_{5}\right)(\mathrm{dppb})$ & dioxane & $88(73)$
\end{tabular}

${ }^{a}$ Conditions: $\mathrm{Pd}$ (0.01 eq.), benzoxazole (2 eq.), 4-bromoacetophenone (1 eq.), $\mathrm{Cs}_{2} \mathrm{CO}_{3}$ (2 eq.), $17 \mathrm{~h}, 130{ }^{\circ} \mathrm{C}$, conversion of $4-$ bromoacetophenone, yield in parenthesis is isolated. ${ }^{b} \mathrm{Pd}$ (0.05 eq.), $100^{\circ} \mathrm{C}$.

Then, we studied the scope and limitations of this procedure, using other aryl bromides (Scheme 2, Tables 2-4). 4-Bromobenzaldehyde, 4-bromopropiophenone or 4-trifluoromethylbromobenzene reacted with benzoxazole gave the expected products $\mathbf{2}, \mathbf{3}$ and $\mathbf{5}$ in $77-92 \%$ yields (Table 2, entries 1,2 and 4). Slower reactions were observed using $4-$ bromobenzonitrile or methyl 4-bromobenzoate. However, using longer reaction time $(72 \mathrm{~h})$, very high conversions of these aryl bromides and high yields of coupling products $\mathbf{4}$ and $\mathbf{6}$ were obtained (Table 2, entries 3 and 5). A lower yield of $25 \%$ of 7 was obtained using 4-bromonitrobenzene, due to a moderate conversion of this aryl bromide (Table 2, entry 6). This is probably due to a partial poisoning of the palladium catalyst. Using the electron-rich aryl bromides, 4-bromotoluene or 4-bromoanisole, the products $\mathbf{9}$ and $\mathbf{1 0}$ were obtained in $83 \%$ and $62 \%$ yields, respectively (Table 2, entries 8 and 9). With these two reactants, long reaction times $(72 \mathrm{~h})$ had to be employed in order to obtain high conversions. 4- $N, N$ Dimethylaminobromobenzene led to a moderate yield of $\mathbf{1 1}$ (Table 2, entry 10). This is certainly due to a slow oxidative addition of this strongly deactivated aryl bromide to palladium. With this catalyst, the oxidative addition of the aryl bromides to palladium appears to be the rate-limiting step of the catalytic cycle. For all these reactions, a very high selectivity in favour of the formation of 2-11 was observed. Moreover, the stability of these products seems to be higher than in DMF, and very limited amount of side-products due to partial degradation was detected..$^{9 e}$

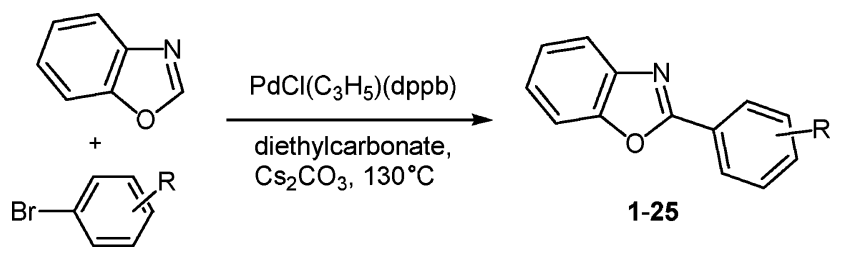

Scheme 2 Coupling of benzoxazole with aryl bromides.

Then, the reactivity of three meta-substituted aryl bromides was examined (Table 3). As expected, similar results than in the presence of para-substituted aryl bromides were obtained. 3-Bromobenzaldehyde, 3-bromobenzonitrile or 3,5bis(trifluoromethyl)bromobenzene gave 12-14 in $85-88 \%$ yields (Table 3, entries 1-3).

Ortho-substituents on aryl bromides generally have a more important influence on the yields of palladium-catalysed re-
Table 2 Palladium-catalysed coupling of benzoxazole with parasubstituted aryl bromides (Scheme 2)

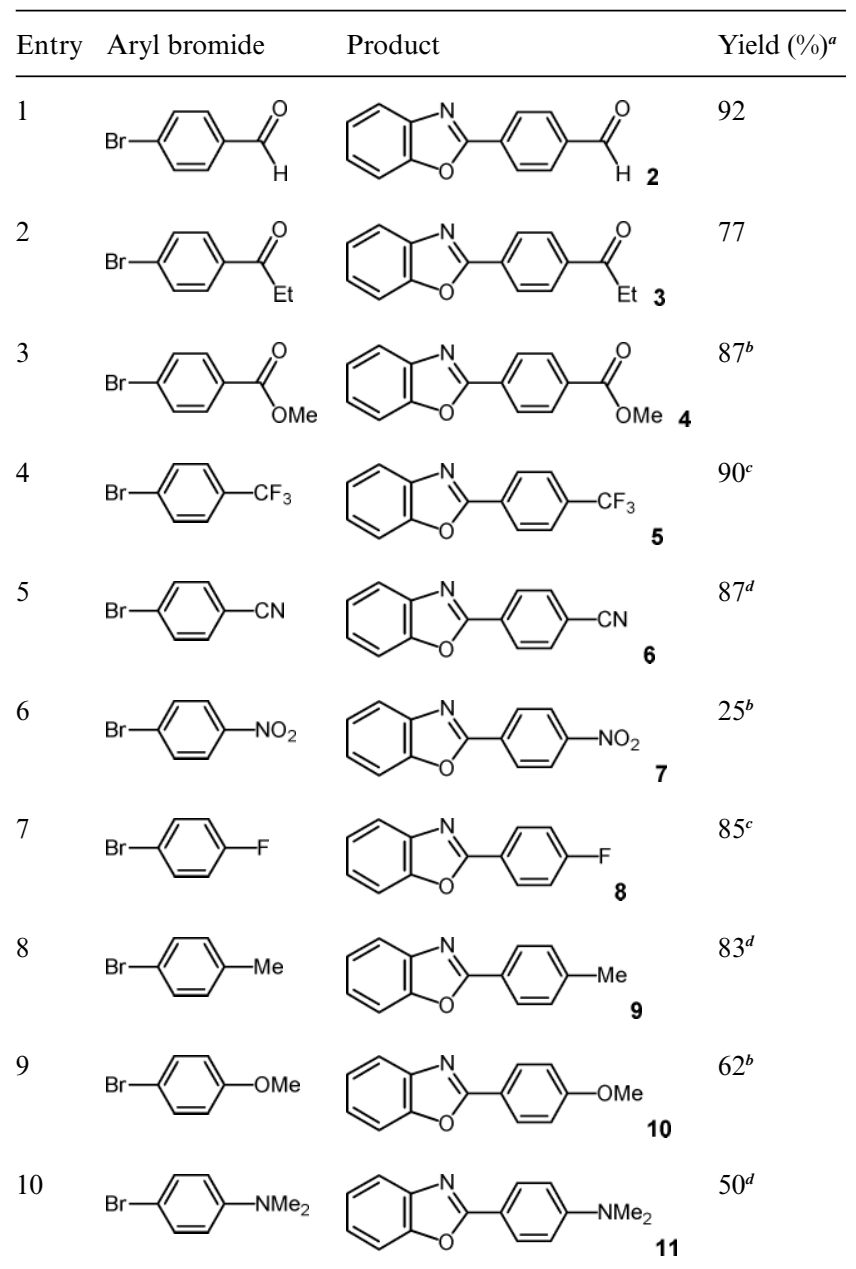

${ }^{a}$ Conditions: $\mathrm{PdCl}\left(\mathrm{C}_{3} \mathrm{H}_{5}\right)(\mathrm{dppb})(0.01$ eq.), benzoxazole (2 eq.), aryl bromide (1 eq.), $\mathrm{Cs}_{2} \mathrm{CO}_{3}$ (2 eq.), diethylcarbonate, $130^{\circ} \mathrm{C}, 17 \mathrm{~h}$, isolated yields. ${ }^{b}$ Reaction time 48 h. ${ }^{c}$ Reaction time 24 h. ${ }^{d}$ Reaction time $72 \mathrm{~h}$.

actions, due to their steric or coordination properties. Ortho-substituted 2-bromobenzaldehyde, 2-bromobenzonitrile, 2bromobenzotrifluoride or 2-fluorobromobenzene reacted with benzoxazole gave 15-18 in 62-90\% yields (Table 2, entries 4-6). Remarkably, the reaction was also successfully realized with the congested and slightly deactivated aryl bromide, 2bromotoluene to give 19 , albeit in moderate $50 \%$ yield (Table 2 , entry 8).

Next, we explored the reactivity of benzoxazole with heteroaryl bromides. The results depicted in Table 4 also revealed clearly the good performance of the novel friendly protocol in direct coupling with benzoxazole. Selective reactions were observed using 2-, 3- or 4-bromopyridines, 3-bromoquinoline, 4-bromoisoquinoline or 5-bromopyrimidine. With these substrates the target products $\mathbf{2 0 - 2 5}$ were obtained in $64-91 \%$ yields. The reaction in the presence of 4-bromoisoquinoline was found to be quite slow. However, a high yield of $\mathbf{2 4}$ was obtained after $48 \mathrm{~h}$ (Table 4 , entry 5 ).

It should be noted that the direct coupling of benzoxazole with 4-bromoacetophenone using propylene carbonate as the 
Table 3 Palladium-catalysed coupling of benzoxazole with meta- or ortho-substituted aryl bromides (Scheme 2)

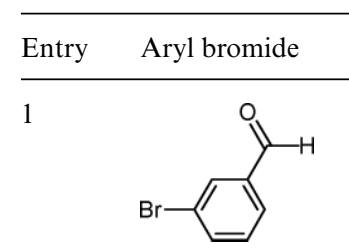

2<smiles>N#Cc1cccc(Br)c1</smiles>

3<smiles>FC(F)(F)c1cc(Br)cc(C(F)(F)F)c1</smiles>

4<smiles>O=Cc1ccccc1Br</smiles>

5<smiles>N#Cc1ccccc1Br</smiles>

6<smiles>FC(F)(F)c1ccccc1Br</smiles>

7<smiles>Fc1ccccc1Br</smiles>

8

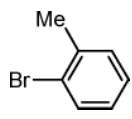<smiles>N#Cc1cccc(-c2nc3ccccc3o2)c1</smiles><smiles>CC(C)(C)c1cc(-c2nc3ccccc3o2)cc(C(F)(F)F)c1</smiles><smiles>O=Cc1ccccc1-c1nc2ccccc2o1</smiles><smiles>N#Cc1ccccc1-c1nc2ccccc2o1</smiles><smiles>FC(F)(F)c1cc[14c]cc1-c1nc2ccccc2o1</smiles><smiles>Fc1cc[13cH]cc1-c1nc2ccccc2o1</smiles>

Yield (\%) ${ }^{a}$

85

88

86

62

$84^{b}$

$90^{b}$

$78^{b}$

50

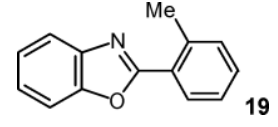

Table 4 Palladium-catalysed coupling of benzoxazole with heteroaryl bromides (Scheme 2)

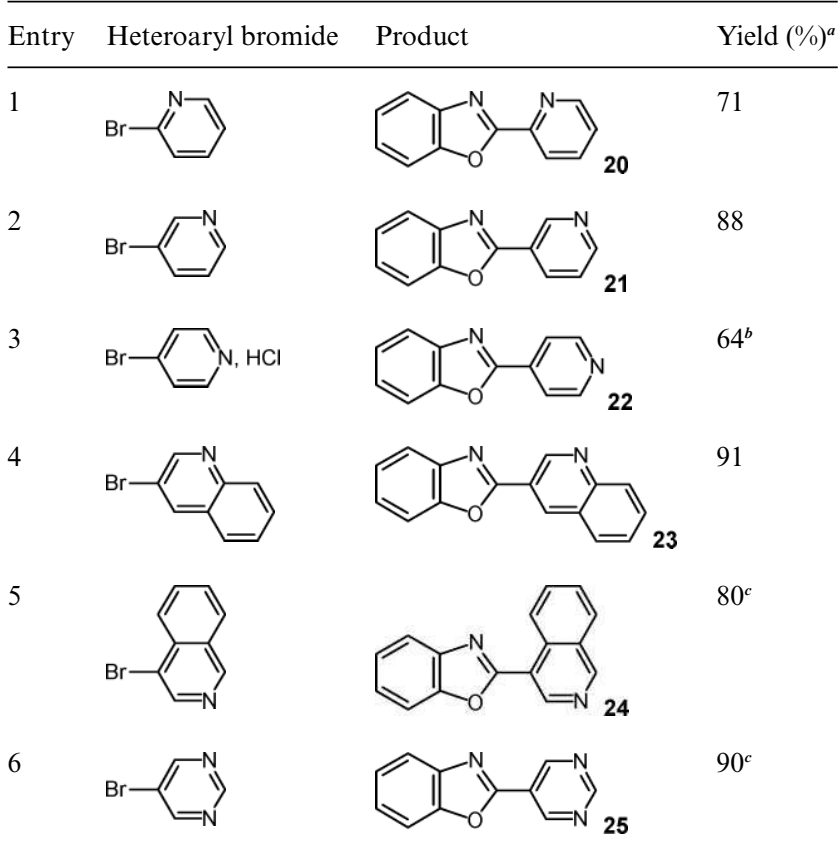

${ }^{a}$ Conditions: $\mathrm{PdCl}\left(\mathrm{C}_{3} \mathrm{H}_{5}\right)(\mathrm{dppb})(0.01$ eq.), benzoxazole (2 eq.), heteroaryl bromide (1 eq.), $\mathrm{Cs}_{2} \mathrm{CO}_{3}$ (2 eq.), diethylcarbonate, $130{ }^{\circ} \mathrm{C}, 24 \mathrm{~h}$, isolated yields. ${ }^{b} \mathrm{Cs}_{2} \mathrm{CO}_{3} 3$ eq. ${ }^{c}$ Reaction time $48 \mathrm{~h}$.

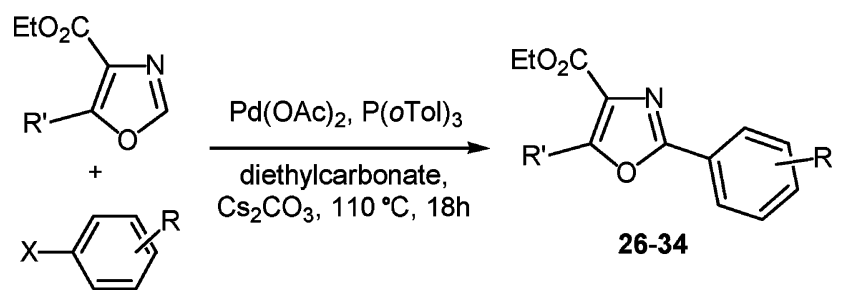

Scheme 4 Coupling of ethyl oxazole-4-carboxylate with aryl halides.

${ }^{a}$ Conditions: $\mathrm{PdCl}\left(\mathrm{C}_{3} \mathrm{H}_{5}\right)(\mathrm{dppb})(0.01$ eq.), benzoxazole (2 eq.), aryl bromide (1 eq.), $\mathrm{Cs}_{2} \mathrm{CO}_{3}$ (2 eq.), diethylcarbonate, $130^{\circ} \mathrm{C}, 17 \mathrm{~h}$, isolated yields. ${ }^{b}$ Reaction time $48 \mathrm{~h}$.

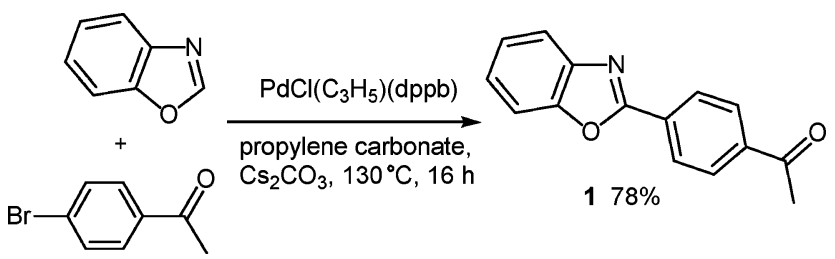

Scheme 3 Coupling of benzoxazole with 4-bromoacetophenone using propylene carbonate as the solvent.

solvent also proceeded nicely, to give $\mathbf{1}$ in 78\% yield (Scheme 3). This solvent is also considered as a "green" alternative to DMF, NMP or DMAc. ${ }^{14,15}$

As a practical and valuable functionalised oxazole substrate, ethyl oxazole-4-carboxylate was recently successfully evaluated in palladium-catalyzed regioselective 2-(hetero)arylation with a broad variety of iodo, bromo and chloro(hetero)aromatics (Scheme 4). ${ }^{\text {aa,9g }}$ Pleasingly, a preliminary assay of direct cou- pling of ethyl oxazole-4-carboxylate with 4-bromoacetophenone under previously designed conditions $\mathrm{Pd}(\mathrm{OAc})_{2} / \mathrm{P}(\mathrm{oTol})_{3},{ }^{9 \mathrm{~g}}$ in diethylcarbonate as the solvent, gave the expected 2-arylated oxazole 26 in $56 \%$ yield (Table 5, entry 1). It should be noted that the use of $\mathrm{PdCl}\left(\mathrm{C}_{3} \mathrm{H}_{5}\right)(\mathrm{dppb})$ as the catalyst proved to be less effective, leading to a poor conversion of starting material $(<20 \%)$ within $48 \mathrm{~h}$. Under the same experimental conditions, the direct arylation of ethyl oxazole-4-carboxylate with several iodo and bromo(hetero)aromatics bearing electron-attractive as well as electron-donating groups were successfully achieved to afford 2-arylated oxazoles 27-30 in good yields (Table 5, entries 2, 4-6). Notably, the novel friendly catalyst system preserve the regiochemical outcome of the direct arylation at the 2position and proved to be as efficient as the previously designed system. $^{9 \mathrm{~g}}$ Indeed, in the course of this reaction, complete conversion of starting material was observed and the 5-arylated and 2,5-diarylated oxazole-4-carboxylates were isolated in very low yields $(<10 \%)$. Interestingly, under the same conditions, activated chloro(hetero)aromatics (Table 5, entry 3) appeared to be also useful coupling partners to give selectively the 
Table 5 Palladium-catalysed coupling of ethyl oxazole-4-carboxylate derivatives with aryl halides (Scheme 4)

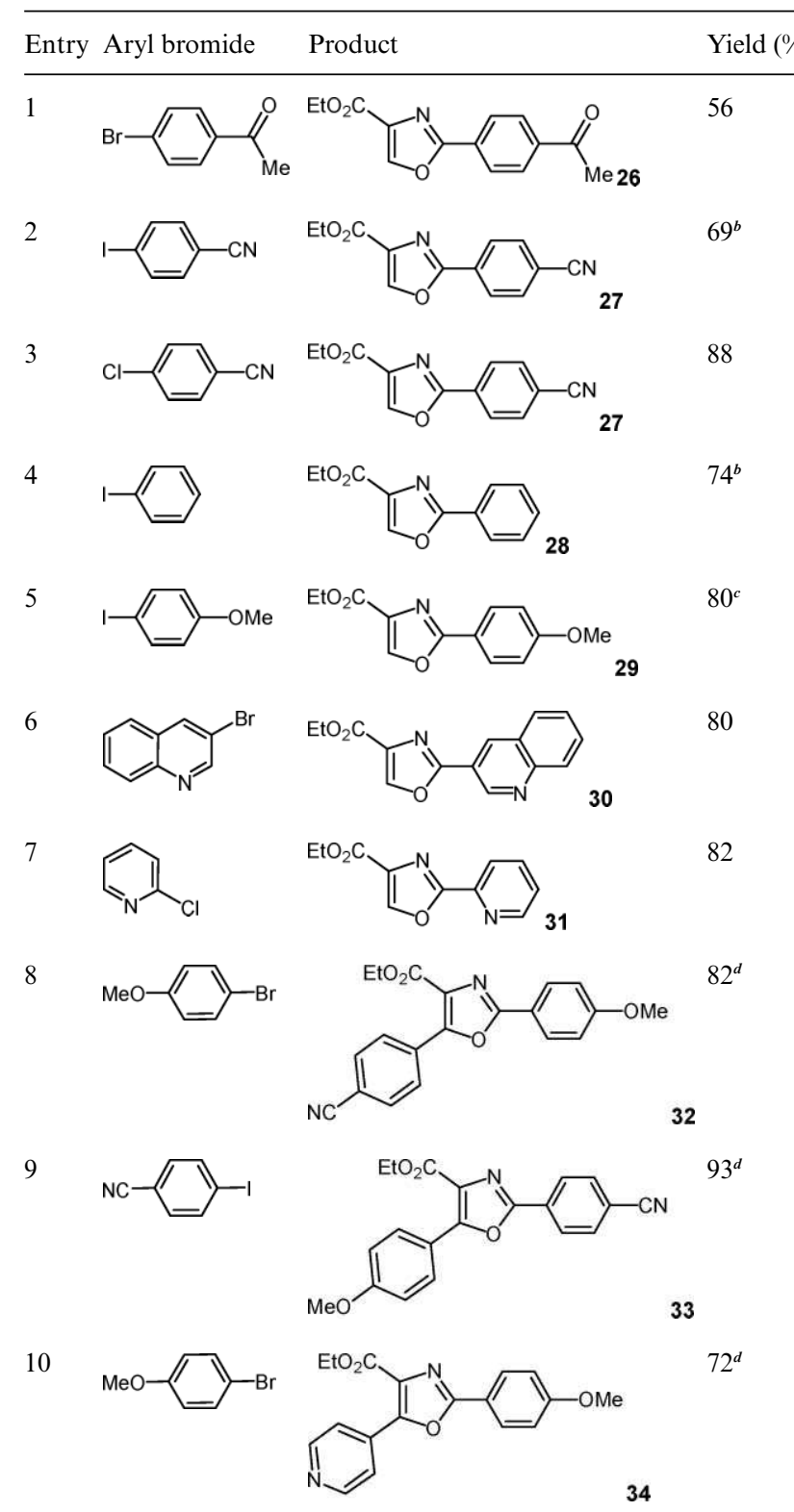

${ }^{a}$ Conditions: $\mathrm{Pd}(\mathrm{OAc})_{2}$ (0.05 eq. $), \mathrm{P}(o \mathrm{Tol})_{3}(0.1$ eq. $)$, ethyl oxazole-4carboxylate (2 eq.), aryl halide (1 eq.), $\mathrm{Cs}_{2} \mathrm{CO}_{3}$ (2 eq.), diethylcarbonate, $110{ }^{\circ} \mathrm{C}, 18 \mathrm{~h}$, isolated yields. ${ }^{b} 5$-Arylation and 2,5-diarylation products were also isolated $(<10 \%)$. ${ }^{c} 2,5$-Diarylation product was also isolated $(<10 \%) .{ }^{d}$ Oxazole derivative: 1 eq.

2-(hetero)arylated oxazole-4-carboxylates 27 and $\mathbf{3 1}$ in good yields.

Moreover, the 5-arylated and heteroarylated oxazoles ${ }^{9 g}$ showed also a good reactivity in the same experimental conditions providing the 2,5-di(hetero)aryled oxazole-4-carboxylates 32-34 (Table 5, entries 8-10).

Then, we examined the reactivity of thiazole derivatives for the direct arylation in diethylcarbonate (Table 6). Using the quite similar reaction conditions $\mathrm{PdCl}\left(\mathrm{C}_{3} \mathrm{H}_{5}\right)(\mathrm{dppb}), 130^{\circ} \mathrm{C}$ and KOAc instead of $\mathrm{Cs}_{2} \mathrm{CO}_{3}$, 2-n-propylthiazole was successfully regioselectively arylated on carbon 5 . The reaction was found to be
Table 6 Palladium-catalysed coupling of thiazole derivatives with aryl halides

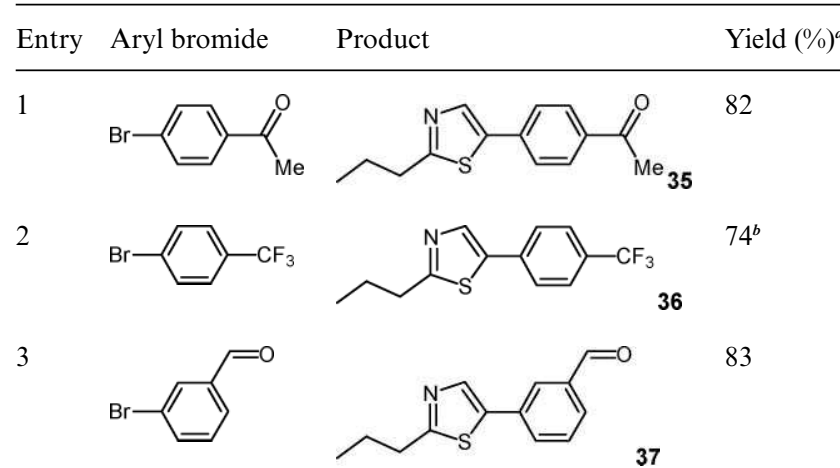

4<smiles>N#Cc1ccccc1Br</smiles><smiles></smiles>

5<smiles>Brc1ccc2ccccc2c1</smiles><smiles>CCCc1ncc(-c2ccc3ccccc3c2)s1</smiles>

6<smiles>Brc1cccnc1</smiles><smiles>CCCc1ncc(-c2ccc[n+]([O-])c2)s1</smiles>

7<smiles>Cl[n+]1ccc(Br)cc1</smiles><smiles>CCCc1ncc(-c2ccncc2)s1</smiles>

8<smiles>Brc1cnc2ccccc2c1</smiles><smiles>CCCc1ncc(-c2cnc3ccccc3c2)s1</smiles>

9<smiles>O=Cc1ccc(Br)cc1</smiles><smiles>CCc1nc(C)c(-c2ccc(C=O)cc2)s1</smiles>

10<smiles>N#Cc1ccccc1Br</smiles><smiles>CCc1nc(C)c(-c2ccccc2C#N)s1</smiles>

11<smiles>Cl[n+]1ccc(Br)cc1</smiles><smiles>CCc1nc(C)c(-c2ccncc2)s1</smiles>

12<smiles>CC(=O)c1ccc(Br)cc1</smiles><smiles>CC(=O)c1ccc(-c2scnc2C)cc1</smiles><smiles>N#Cc1ccc(Br)cc1</smiles><smiles>Cc1ncsc1-c1ccc(C#N)cc1</smiles>

14<smiles>CC(=O)c1cccc(Br)c1</smiles><smiles>CC(=O)c1cccc(-c2scnc2C)c1</smiles>

15<smiles>Brc1cnc2ccccc2c1</smiles> 
Table 6 (Contd.)

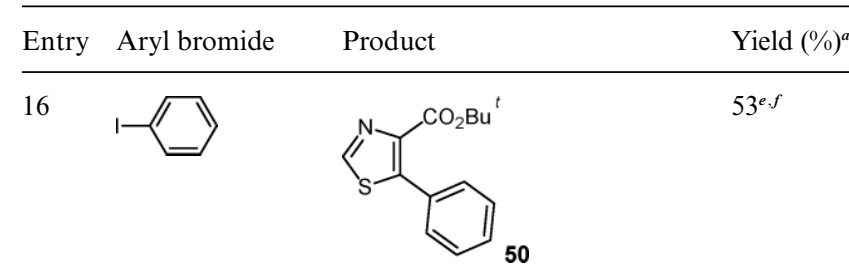

17
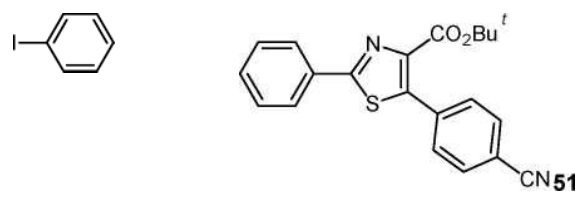

$70^{g}$

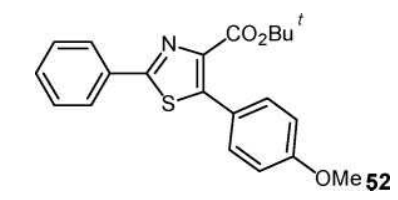

$83^{g}$

18

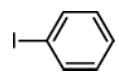

${ }^{a}$ Conditions: $\mathrm{PdCl}\left(\mathrm{C}_{3} \mathrm{H}_{5}\right)(\mathrm{dppb})(0.01$ eq. $)$, thiazole derivative (2 eq.), aryl halide (1 eq.), KOAc (2 eq.), diethylcarbonate, $130{ }^{\circ} \mathrm{C}, 24 \mathrm{~h}$, isolated yields. ${ }^{b} 24 \mathrm{~h} .^{c} 67 \mathrm{~h}^{d}{ }^{d} 140^{\circ} \mathrm{C} .{ }^{e} \mathrm{Pd}(\mathrm{OAc})_{2}(0.05$ eq. $), \mathrm{P}(o \mathrm{Tol})_{3}(0.1$ eq. $)$, $\mathrm{Cs}_{2} \mathrm{CO}_{3}$ (2 eq.), $110^{\circ} \mathrm{C}, 18 \mathrm{~h} .{ }^{f}$ 2,5-Diphenylatedthiazole was isolated in $23 \%$ yield. ${ }^{g} \mathrm{Pd}(\mathrm{OAc})_{2}(0.05$ eq. $), \mathrm{P}(o \mathrm{Tol})_{3}(0.1$ eq. $)$, iodobenzene ( 2 eq. $)$, thiazole derivative (1 eq.), $\mathrm{Cs}_{2} \mathrm{CO}_{3}$ (2 eq.), $130{ }^{\circ} \mathrm{C}, 18 \mathrm{~h}$.

slower than in DMAc, ${ }^{8 \mathrm{~d}}$ however, very high yields of compound 35-42 were obtained (Table 6, entries 1-8). As expected, the use of 2-ethyl-4-methylthiazole also allowed the synthesis of the 5arylated thiazoles 43-45 in high yields (Table 6, entries 9-11). We also studied this reaction using 4-methylthiazole (Table 6, entries 12-15). With this substrate, we could have observed the formation of the 2- or 5-arylation products. However, in all cases, only the 5-arylation products $\mathbf{4 6}-\mathbf{4 9}$ were isolated.

The structurally-related thiazole-4-carboxylate series was recently successfully evaluated in palladium-catalyzed direct (hetero)arylation with halo(hetero)aromatics. ${ }^{8 c}$ Starting with tertbutylthiazole-4-carboxylate, both $\mathrm{P}(o \text {-tol })_{3}$ and Cy-JohnPhos ligands in DMF were selected for the coupling of iodoaromatics and bromo- and chloroaromatics, respectively, in DMF as solvent, whilst the use of toluene under the same conditions led to a better selectivity for the 5-position, albeit in more modest yields. ${ }^{8 c}$ Thus, the preliminary assay of direct coupling of tertbutylthiazole-4-carboxylate with iodobenzene under previously designed conditions $\mathrm{Pd}(\mathrm{OAc})_{2} / \mathrm{P}(o \mathrm{Tol})_{3}$ in diethylcarbonate as the solvent was consistent with our previous observations in toluene. Indeed, the 5-phenylthiazole-4-carboxylate $\mathbf{5 0}$ was isolated as the major product in $53 \%$ yield (Table 6 , entry 16 ). Nevertheless, under the same conditions but by allowing the temperature to $130{ }^{\circ} \mathrm{C}$, the 5-arylated thiazole-4-carboxylate were also successful phenylated providing the 2,5-diarylated thiazole-4-carboxylates $\mathbf{5 1}$ and $\mathbf{5 2}$ in good yields independently to the electronic effect on the aromatic (Table 6, entries 17 and 18).

Benzothiazole was found to be less reactive than benzoxazole. However, when we employed a more elevated temperature $\left(140{ }^{\circ} \mathrm{C}\right.$ instead of $\left.130{ }^{\circ} \mathrm{C}\right)$, for the coupling with 4 bromobenzaldehyde, a high yield of $89 \%$ of the 2-arylated
Table 7 Palladium-catalysed coupling of 2-n-butylfuran with aryl bromides

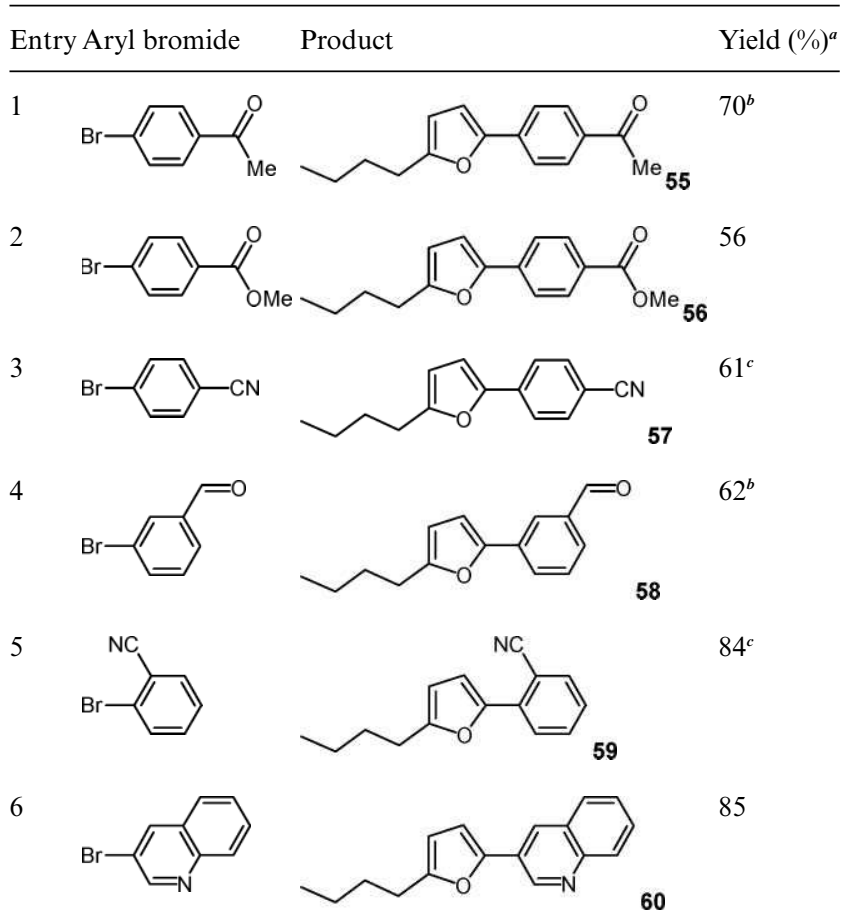

${ }^{a}$ Conditions: $\mathrm{PdCl}\left(\mathrm{C}_{3} \mathrm{H}_{5}\right)(\mathrm{dppb})(0.01$ eq. $)$, furan derivative (2 eq.), aryl bromide ( 1 eq.), KOAc ( 2 eq.), diethylcarbonate, $140{ }^{\circ} \mathrm{C}, 23 \mathrm{~h}$, isolated yields. ${ }^{b} 72$ h. $^{c} 43 \mathrm{~h}$.

product 48 was obtained (Scheme 5). Using these reaction conditions, the coupling with 2-bromobenzonitrile gave 49 in $52 \%$ yield.

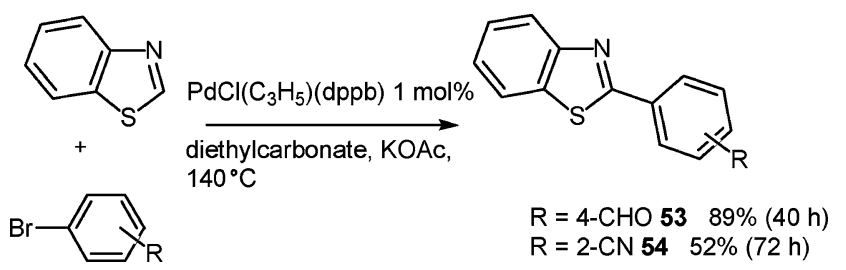

Scheme 5 Coupling of benzothiazole with 4-bromobenzaldehyde.

The direct use of furan derivatives is an important field for research in green chemistry, since some of them can be obtained from agricultural wastes rich in pentosan polymers. Our first attempts to arylate 2-n-butylfuran with 4-bromoacetophenone using $130{ }^{\circ} \mathrm{C}$ as the reaction temperature gave very low yields of 55. On the other hand, we observed that using a more elevated reaction temperature of $140{ }^{\circ} \mathrm{C}$, a moderate yield of 55 could be obtained after $23 \mathrm{~h}$. As the catalyst appears to be quite stable in this solvent, the use of longer reaction times ( 43 or $72 \mathrm{~h}$ ) allowed to obtain the 5-arylated furans in good yields (Table 7). For example, after 43 or $72 \mathrm{~h}$, the reaction of 2-n-butylfuran with 2-bromobenzonitrile or 4-bromoacetophenone gave $\mathbf{5 9}$ and $\mathbf{5 5}$ in $84 \%$ and $70 \%$ yields, respectively. In all cases, the reaction was very regioselective in favour of the 5-arylation.

The reactivity or 2-n-butylthiophene was found to be similar to 2-n-butylfuran (Table 8). When we employed $140{ }^{\circ} \mathrm{C}$ as the 
Table 8 Palladium-catalysed coupling of 2-n-butylthiophene with aryl bromides

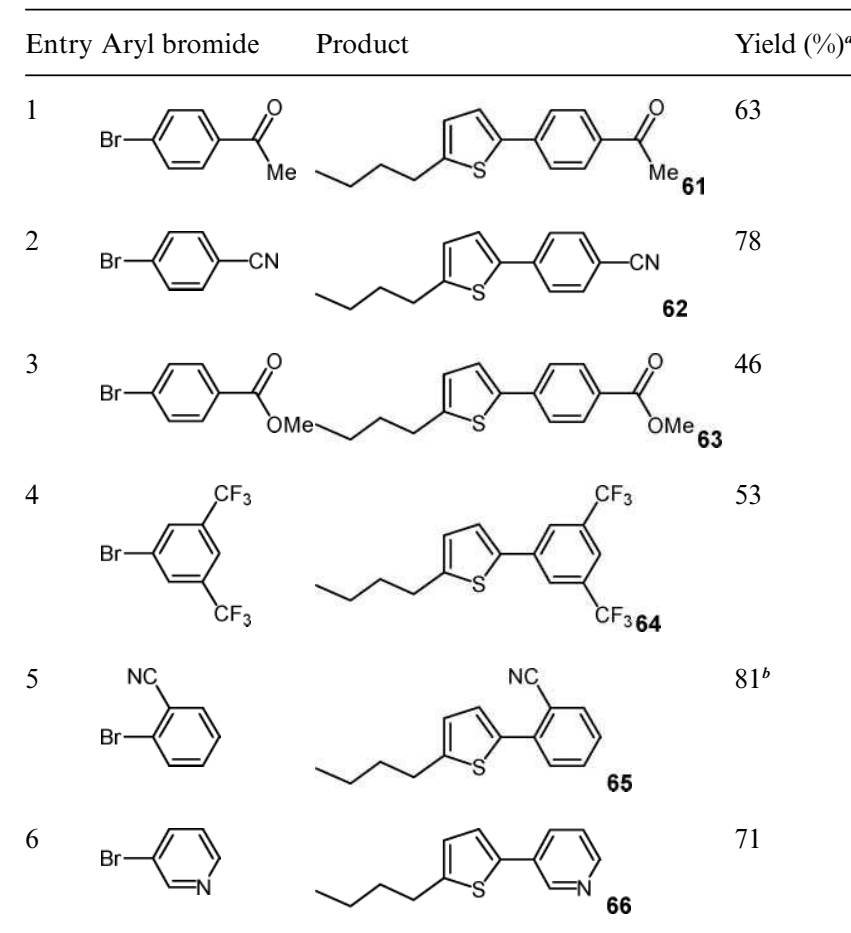

${ }^{a}$ Conditions: $\mathrm{PdCl}\left(\mathrm{C}_{3} \mathrm{H}_{5}\right)(\mathrm{dppb})(0.01$ eq. $)$, thiophene derivative (2 eq.), aryl bromide ( 1 eq.), KOAc (2 eq.), diethylcarbonate, $140{ }^{\circ} \mathrm{C}, 72 \mathrm{~h}$, isolated yields. ${ }^{b} 17 \mathrm{~h}$.

reaction temperature, a variety of aryl bromides was coupled to give 61-66 in moderate to good yields. Again, the arylation was highly regioselective in favour of the 5 -arylation. The moderate yields obtained in the presence of methyl 4-bromobenzoate or 3,5-bis(trifluoromethyl)bromobenzene are due to partial conversions of these aryl bromides.

Then, three arylated isoxazoles have been prepared via the direct 4-arylation of 3,5-dimethylisoxazole (Table 9). ${ }^{10}$ The yields strongly depend on the nature of the aryl bromides. A good yield of $71 \%$ of $\mathbf{6 7}$ was obtained in the presence of $4-$ bromoacetophenone; whereas, the use of 2-bromobenzonitrile gave $\mathbf{6 9}$ in only $23 \%$ yield.

1-Methyl-2-formylpyrrole has a poor reactivity for direct arylation in diethylcarbonate (Table 10). Much slower reactions than in DMAc were observed, ${ }^{6 e}$ and low to moderate yields were obtained. For example the coupling of 4-bromobenzonitrile with this reactant gave the 5 -arylated pyrrole $\mathbf{7 1}$ in only $33 \%$ yield.

We have already reported the direct 5 -arylation of a range of imidazole derivatives in DMAc. ${ }^{7 f}$ Again, the arylations were found to be slower in diethylcarbonate than in DMAc, however, the reactions were very clean using a range of aryl bromides (Table 11). High conversions of 4-bromoacetophenone, 4bromobenzonitrile or 3-bromopyridine were observed, and 73, 74 and 76 were obtained in high yields. On the other hand, only a partial conversion of 4-trifluoromethylbromobenzene was observed leading to a moderate yield of $\mathbf{7 5}$.

In conclusion, these results demonstrate that carbonates, which are considered to be "green solvents", can be advantageously employed as an alternative to the solvents usually used
Table 9 Palladium-catalysed coupling of 2,4-dimethylisoxazole with aryl bromides

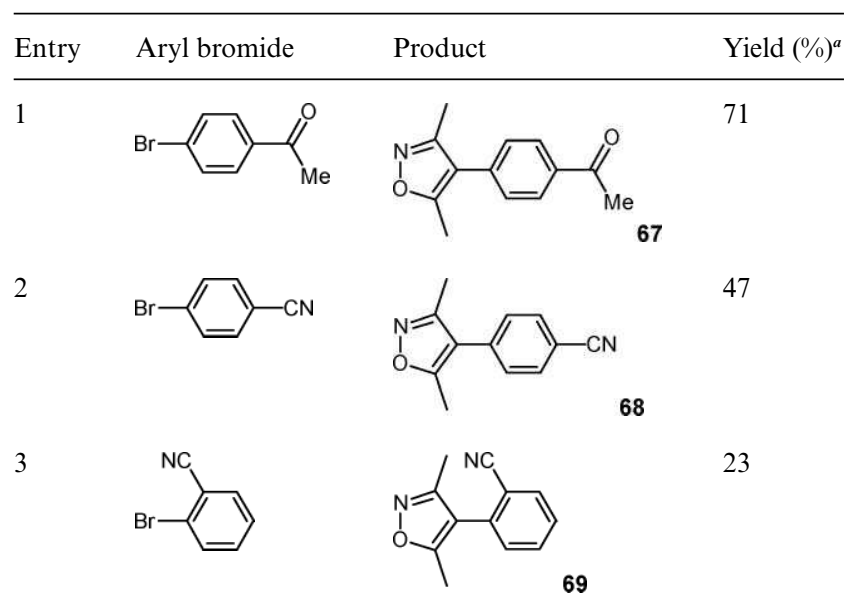

${ }^{a}$ Conditions: $\mathrm{PdCl}\left(\mathrm{C}_{3} \mathrm{H}_{5}\right)(\mathrm{dppb})$ (0.01 eq.), 2,4-dimethylisoxazole ( 2 eq.), aryl bromide ( 1 eq.), KOAc (2 eq.), diethylcarbonate, $140{ }^{\circ} \mathrm{C}$, $72 \mathrm{~h}$, isolated yields.

Table 10 Palladium-catalysed coupling of 1-methyl-2-formylpyrrole with aryl bromides

\begin{tabular}{llll}
\hline Entry Aryl bromide & Product & Yield (\%) \\
\hline
\end{tabular}

2

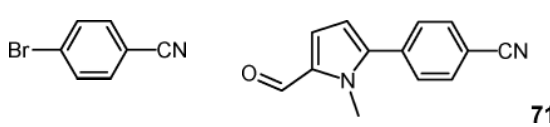

3

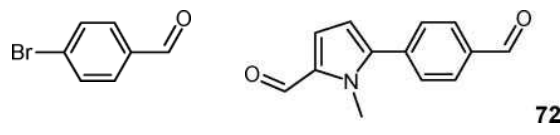

33

35

${ }^{a}$ Conditions: $\mathrm{PdCl}\left(\mathrm{C}_{3} \mathrm{H}_{5}\right)(\mathrm{dppb})(0.01$ eq. $)$, 1-methyl-2-formylpyrrole (2 eq.), aryl bromide (1 eq.), $\mathrm{Cs}_{2} \mathrm{CO}_{3}$ (2 eq.), diethylcarbonate, $140{ }^{\circ} \mathrm{C}$, $72 \mathrm{~h}$, isolated yields. ${ }^{b} 42 \mathrm{~h}$.

for the direct arylation of several heteroaromatic derivatives. In the presence of diethylcarbonate or propylene carbonate and $1 \mathrm{~mol} \% \mathrm{PdCl}\left(\mathrm{C}_{3} \mathrm{H}_{5}\right)(\mathrm{dppb})$ as the catalyst precursor at $130{ }^{\circ} \mathrm{C}$, the direct 2-arylation of benzoxazole, ethyl oxazole-4carboxylate or the 5-arylation of thiazoles using aryl bromides as coupling partners proceeds in moderate to high yields. The direct arylation of furan, thiophene, pyrrole, imidazole or isoxazole derivatives was found to require a more elevated reaction temperature $\left(140{ }^{\circ} \mathrm{C}\right)$ to give high yields of coupling products. It should be noted that a wide range of functions such as acetyl, propionyl, formyl, ester, nitrile, trifluoromethyl, fluoro or methoxy on the aryl halide is tolerated. The major by-product of these couplings is $\mathrm{CsX}$ or $\mathrm{KX} / \mathrm{AcOH}$ instead of metallic salts with more classical coupling procedures. For these reasons, this novel process should give an economically viable and environmentally attractive access to arylated heteroaromatics. 
Table 11 Palladium-catalysed coupling of 1,2-dimethylimidazole with aryl bromides

Entry Aryl bromide Yield (\%)

${ }^{a}$ Conditions: $\mathrm{PdCl}\left(\mathrm{C}_{3} \mathrm{H}_{5}\right)(\mathrm{dppb}) \quad(0.01$ eq. $)$, 1,2-dimethylimidazole ( 2 eq.), aryl bromide (1 eq.), KOAc $\left(2\right.$ eq.), diethylcarbonate, $140{ }^{\circ} \mathrm{C}$, $72 \mathrm{~h}$, isolated yields. ${ }^{b} 48 \mathrm{~h}$.

\section{Experimental}

Diethylcarbonate was purchased from Acros Organics and was not purified before use. Heteroarenes, propylene carbonate, KOAc and $\mathrm{Cs}_{2} \mathrm{CO}_{3}$ were purchased from Alfa Aesar and were not purified before use. Ethyl oxazole-4-carboxylate was prepared from ethyl isocyanoacetate according to Schöllkopf procedure. $^{18}$

\section{Preparation of the $\mathrm{PdCl}\left(\mathrm{C}_{3} \mathrm{H}_{5}\right)(\mathrm{dppb})$ catalyst: $^{19}$}

An oven-dried $40 \mathrm{~mL}$ Schlenk tube equipped with a magnetic stirring bar under argon atmosphere, was charged with $\left[\mathrm{Pd}\left(\mathrm{C}_{3} \mathrm{H}_{5}\right) \mathrm{Cl}\right]_{2}(182 \mathrm{mg}, 0.5 \mathrm{mmol})$ and dppb (426 mg, $\left.1 \mathrm{mmol}\right)$. $10 \mathrm{~mL}$ of anhydrous dichloromethane were added, then the solution was stirred at room temperature for twenty minutes. The solvent was removed in vacuum. The yellow powder was used without purification. ${ }^{31} \mathrm{P}$ NMR (81 $\mathrm{MHz}, \mathrm{CDCl}_{3}$ ) $\delta=19.3$ (s).

\section{Typical experiment for coupling reactions}

The reaction of the aryl halide $(1 \mathrm{mmol})$, heteroaromatic (2 mmol) and $\mathrm{Cs}_{2} \mathrm{CO}_{3}(0.651 \mathrm{~g}, 2 \mathrm{mmol})$ or KOAc (0.196, $2 \mathrm{mmol}$ ) (see Tables) at $130-140{ }^{\circ} \mathrm{C}$ (see Tables and Schemes) in diethylcarbonate $(5 \mathrm{~mL})$ in the presence of $\mathrm{PdCl}\left(\mathrm{C}_{3} \mathrm{H}_{5}\right)(\mathrm{dppb})$ $(6.1 \mathrm{mg}, 0.01 \mathrm{mmol})$ or $\mathrm{Pd}(\mathrm{OAc})_{2}(0.05$ eq. $) / \mathrm{P}(o \mathrm{Tol})_{3}(0.1$ eq. $)$, (see Tables and Schemes) under argon affords the corresponding product after evaporation and filtration on silica gel (pentane/ether).

\section{2-(4-Acetylphenyl)-benzoxazole (1) ${ }^{9 \mathrm{e}}$}

4-Bromoacetophenone $(0.199 \mathrm{~g}, 1 \mathrm{mmol})$ and benzoxazole $(0.238 \mathrm{~g}, 2 \mathrm{mmol})$ affords 1 in $85 \%(0.202 \mathrm{~g})$ yield.

\section{2-(4-Formylphenyl)-benzoxazole (2)}

4-Bromobenzaldehyde (0.184 $\mathrm{g}, 1 \mathrm{mmol})$ and benzoxazole $(0.238 \mathrm{~g}, 2 \mathrm{mmol})$ affords 2 in $92 \%(0.205 \mathrm{~g})$ yield.

\section{2-(4-Propionylphenyl)-benzoxazole (3)}

4-Bromopropiophenone $(0.213 \mathrm{~g}, 1 \mathrm{mmol})$ and benzoxazole $(0.238 \mathrm{~g}, 2 \mathrm{mmol})$ affords 3 in $77 \%(0.193 \mathrm{~g})$ yield.

\section{Methyl 4-benzoxazol-2-yl-benzoate (4) ${ }^{9 \mathrm{e}}$}

Methyl 4-bromobenzoate $(0.215 \mathrm{~g}, 1 \mathrm{mmol})$ and benzoxazole $(0.238 \mathrm{~g}, 2 \mathrm{mmol})$ affords 4 in $87 \%(0.220 \mathrm{~g})$ yield.

\section{2-(4-Trifluoromethylphenyl)-benzoxazole (5) ${ }^{9 \mathrm{e}}$}

4-Trifluoromethylbromobenzene $(0.225 \mathrm{~g}, 1 \mathrm{mmol})$ and benzoxazole $(0.238 \mathrm{~g}, 2 \mathrm{mmol})$ affords 5 in $90 \%(0.237 \mathrm{~g})$ yield.

\section{4-Benzoxazol-2-yl-benzonitrile (6)}

4-Bromobenzonitrile $(0.182 \mathrm{~g}, 1 \mathrm{mmol})$ and benzoxazole $(0.238 \mathrm{~g}, 2 \mathrm{mmol})$ affords 6 in $87 \%(0.192 \mathrm{~g})$ yield.

\section{2-(4-Nitrophenyl)-benzoxazole (7) ${ }^{9 \mathrm{e}}$}

4-Bromonitrobenzene $(0.182 \mathrm{~g}, 1 \mathrm{mmol})$ and benzoxazole $(0.238 \mathrm{~g}, 2 \mathrm{mmol})$ affords 7 in $25 \%(0.060 \mathrm{~g})$ yield.

\section{2-(4-Fluorophenyl)-benzoxazole $(8)^{9 \mathrm{e}}$}

4-Bromofluorobenzene $(0.175 \mathrm{~g}, 1 \mathrm{mmol})$ and benzoxazole $(0.238 \mathrm{~g}, 2 \mathrm{mmol})$ affords 8 in $85 \%(0.181 \mathrm{~g})$ yield.

\section{2-(4-Methylphenyl)-benzoxazole (9) ${ }^{9 e}$}

4-Bromotoluene $(0.171 \mathrm{~g}, 1 \mathrm{mmol})$ and benzoxazole $(0.238 \mathrm{~g}$, $2 \mathrm{mmol})$ affords 9 in $83 \%(0.174 \mathrm{~g})$ yield.

\section{2-(4-Methoxyphenyl)-benzoxazole (10) $)^{9 e}$}

4-Bromoanisole $(0.187 \mathrm{~g}, 1 \mathrm{mmol})$ and benzoxazole $(0.238 \mathrm{~g}$, $2 \mathrm{mmol})$ affords 10 in $62 \%(0.140 \mathrm{~g})$ yield.

\section{2-(4-Dimethylaminophenyl)-benzoxazole (11) ${ }^{9 \mathrm{e}}$}

(4-Bromophenyl)-dimethylamine $(0.200 \mathrm{~g}, 1 \mathrm{mmol})$ and benzoxazole $(0.238 \mathrm{~g}, 2 \mathrm{mmol})$ affords 11 in $50 \%$ (0.119 g) yield.

\section{2-(3-Formylphenyl)-benzoxazole (12)}

3-Bromobenzaldehyde $(0.184 \mathrm{~g}, 1 \mathrm{mmol})$ and benzoxazole $(0.238 \mathrm{~g}, 2 \mathrm{mmol})$ affords 12 in $85 \%(0.190 \mathrm{~g})$ yield.

\section{3-Benzoxazol-2-yl-benzonitrile (13) ${ }^{9 \mathrm{e}}$}

3-Bromobenzonitrile $(0.182 \mathrm{~g}, 1 \mathrm{mmol})$ and benzoxazole $(0.238 \mathrm{~g}, 2 \mathrm{mmol})$ affords 13 in $88 \%(0.194 \mathrm{~g})$ yield.

\section{2-(3,5-Bistrifluoromethylphenyl)-benzoxazole (14) ${ }^{9 \mathrm{e}}$}

3,5-Bis(trifluoromethyl)bromobenzene $(0.293 \mathrm{~g}, 1 \mathrm{mmol})$ and benzoxazole $(0.238 \mathrm{~g}, 2 \mathrm{mmol})$ affords 14 in $86 \%(0.285 \mathrm{~g})$ yield. 


\section{2-(2-Formylphenyl)-benzoxazole (15)}

2-Bromobenzaldehyde $(0.184 \mathrm{~g}, 1 \mathrm{mmol})$ and benzoxazole $(0.238 \mathrm{~g}, 2 \mathrm{mmol})$ affords 15 in $62 \%(0.138 \mathrm{~g})$ yield.

\section{2-Benzoxazol-2-yl-benzonitrile (16) ${ }^{9 \mathrm{e}}$}

2-Bromobenzonitrile $(0.182 \mathrm{~g}, 1 \mathrm{mmol})$ and benzoxazole $(0.238 \mathrm{~g}, 2 \mathrm{mmol})$ affords 16 in $84 \%(0.185 \mathrm{~g})$ yield.

\section{2-(2-Trifluoromethylphenyl)-benzoxazole (17)}

2-Trifluoromethylbromobenzene $(0.225 \mathrm{~g}, 1 \mathrm{mmol})$ and benzoxazole $(0.238 \mathrm{~g}, 2 \mathrm{mmol})$ affords 17 in $90 \%$ (0.237 g) yield.

\section{2-(2-Fluorophenyl)-benzoxazole (18) ${ }^{9 \mathrm{e}}$}

2-Bromofluorobenzene $(0.175 \mathrm{~g}, 1 \mathrm{mmol})$ and benzoxazole $(0.238 \mathrm{~g}, 2 \mathrm{mmol})$ affords $\mathbf{1 8}$ in $78 \%(0.166 \mathrm{~g})$ yield.

\section{2-(2-Methylphenyl)-benzoxazole (19) ${ }^{9 \mathrm{e}}$}

2-Bromotoluene $(0.171 \mathrm{~g}, 1 \mathrm{mmol})$ and benzoxazole $(0.238 \mathrm{~g}$, $2 \mathrm{mmol})$ affords 19 in 50\% (0.105 g) yield.

\section{2-Pyridin-2-yl-benzoxazole $(\mathbf{2 0})^{9 \mathrm{~h}}$}

2-Bromopyridine $(0.158 \mathrm{~g}, 1 \mathrm{mmol})$ and benzoxazole $(0.238 \mathrm{~g}$, $2 \mathrm{mmol})$ affords 20 in $71 \%(0.139 \mathrm{~g})$ yield.

\section{2-Pyridin-3-yl-benzoxazole $(21)^{9 \mathrm{e}}$}

3-Bromopyridine $(0.158 \mathrm{~g}, 1 \mathrm{mmol})$ and benzoxazole $(0.238 \mathrm{~g}$, $2 \mathrm{mmol})$ affords 21 in $88 \%(0.173 \mathrm{~g})$ yield.

\section{2-Pyridin-4-yl-benzoxazole (22)}

4-Bromopyridine hydrochloride $(0.194 \mathrm{~g}, 1 \mathrm{mmol})$ and benzoxazole $(0.238 \mathrm{~g}, 2 \mathrm{mmol})$ affords 22 in $64 \%$ (0.126 g) yield.

\section{3-Benzoxazol-2-ylquinoline $(23)^{9 \mathrm{e}}$}

3-Bromoquinoline $(0.208 \mathrm{~g}, 1 \mathrm{mmol})$ and benzoxazole $(0.238 \mathrm{~g}$, $2 \mathrm{mmol}$ ) affords 23 in $91 \%(0.224 \mathrm{~g})$ yield.

\section{4-Benzoxazol-2-ylisoquinoline (24)}

4-Bromoisoquinoline $(0.208 \mathrm{~g}, 1 \mathrm{mmol})$ and benzoxazole $(0.238 \mathrm{~g}, 2 \mathrm{mmol})$ affords 24 in $80 \%(0.197 \mathrm{~g})$ yield.

\section{2-Pyrimidin-5-ylbenzoxazole $(25)^{9 \mathrm{e}}$}

5-Bromopyrimidine $(0.159 \mathrm{~g}, 1 \mathrm{mmol})$ and benzoxazole $(0.238 \mathrm{~g}$, $2 \mathrm{mmol})$ affords 25 in $90 \%(0.177 \mathrm{~g})$ yield.

\section{Ethyl 2-(4-acetylphenyl)-oxazole-4-carboxylate (26)}

4-Bromoacetophenone $(0.199 \mathrm{~g}, 1 \mathrm{mmol})$ and ethyloxazole-4carboxylate $(0.282 \mathrm{~g}, 2 \mathrm{mmol})$ affords 26 in $56 \%(0.145 \mathrm{~g})$ yield.

Ethyl 2-(4-cyanophenyl)-oxazole-4-carboxylate (27) ${ }^{9 \mathrm{~g}}$

4-Iodobenzonitrile $(0.229 \mathrm{~g}, 1 \mathrm{mmol})$ and ethyloxazole-4carboxylate $(0.282 \mathrm{~g}, 2 \mathrm{mmol})$ affords 27 in $69 \%(0.167 \mathrm{~g})$ yield.

\section{Ethyl 2-phenyloxazole-4-carboxylate (28) ${ }^{9 \mathrm{~g}}$}

Iodobenzene (0.204 g, $1 \mathrm{mmol})$ and ethyloxazole-4-carboxylate $(0.282 \mathrm{~g}, 2 \mathrm{mmol})$ affords 28 in $74 \%(0.161 \mathrm{~g})$ yield.

\section{Ethyl 2-(4-Methoxyphenyl)-oxazole-4-carboxylate (29) ${ }^{9 \mathrm{~g}}$}

Iodoanisole $(0.234 \mathrm{~g}, 1 \mathrm{mmol})$ and ethyloxazole-4-carboxylate (0.282 g, $2 \mathrm{mmol})$ affords 29 in 80\% (0.198 g) yield.

\section{Ethyl 2-quinolin-3-yloxazole-4-carboxylate (30) ${ }^{9 \mathrm{~g}}$}

3-Bromoquinoline $(0.208 \mathrm{~g}, 1 \mathrm{mmol})$ and ethyloxazole-4carboxylate $(0.282 \mathrm{~g}, 2 \mathrm{mmol})$ affords 30 in $80 \%(0.214 \mathrm{~g})$ yield.

\section{Ethyl 2-pyridin-2-yl-oxazole-4-carboxylate (31) $)^{9 \mathrm{~g}}$}

2-Chloropyridine $(0.113 \mathrm{~g}, 1 \mathrm{mmol})$ and ethyloxazole-4carboxylate $(0.282 \mathrm{~g}, 2 \mathrm{mmol})$ affords 31 in $82 \%(0.179 \mathrm{~g})$ yield.

\section{5-(4-Cyanophenyl)-2-(4-methoxyphenyl)-oxazole-4-carboxylic acid ethyl ester (32)}

4-Bromoanisole $(0.065 \mathrm{~g}, 0.35 \mathrm{mmol})$ and ethyl 5-(4cyanophenyl)oxazole-4-carboxylate ${ }^{9 \mathrm{~g}}(0.085 \mathrm{~g}, 0.35 \mathrm{mmol})$ affords 32 in $82 \%(0.100 \mathrm{~g})$ yield.

2-(4-Cyano-phenyl)-5-(4-methoxy-phenyl)-oxazole-4-carboxylic acid ethyl ester (33)

4-Iodobenzonitrile $(0.080 \mathrm{~g}, 0.35 \mathrm{mmol})$ and ethyl 5-(4methoxyphenyl)oxazole-4-carboxylate ${ }^{9 \mathrm{~g}}(0.086 \mathrm{~g}, 0.35 \mathrm{mmol})$ affords 33 in $93 \%(0.113 \mathrm{~g})$ yield.

\section{2-(4-Methoxyphenyl)-5-pyridin-4-yl-oxazole-4-carboxylic acid ethyl ester (34)}

4-Bromoanisole (0.065 g, $0.35 \mathrm{mmol})$ and ethyl 5-(pyridin-4yl)oxazole-4-carboxylate ${ }^{9 \mathrm{~g}}(0.076 \mathrm{~g}, 0.35 \mathrm{mmol})$ affords 34 in $72 \%(0.082 \mathrm{~g})$ yield.

\section{4-(2-Propylthiazol-5-yl)acetophenone (35) ${ }^{8 a}$}

4-Bromoacetophenone (0.199 g, $1 \mathrm{mmol})$ and 2-npropylthiazole $(0.254 \mathrm{~g}, 2 \mathrm{mmol})$ affords 35 in $82 \%(0.201 \mathrm{~g})$ yield.

\section{5-4-(Trifluoromethyl)phenyl-2-propylthiazole $(36)^{8 a}$}

4-Trifluoromethylbromobenzene $(0.225 \mathrm{~g}, 1 \mathrm{mmol})$ and 2-npropylthiazole $(0.254 \mathrm{~g}, 2 \mathrm{mmol})$ affords 36 in $74 \%(0.201 \mathrm{~g})$ yield.

\section{3-(2-Propylthiazol-5-yl)benzaldehyde (37) ${ }^{8 \mathrm{~d}}$}

3-Bromobenzaldehyde ( $0.184 \mathrm{~g}, 1 \mathrm{mmol})$ and 2-n-propylthiazole $(0.254 \mathrm{~g}, 2 \mathrm{mmol})$ affords 37 in $83 \%(0.192 \mathrm{~g})$ yield.

\section{2-(2-Propylthiazol-5-yl)benzonitrile (38) ${ }^{8 \mathrm{a}}$}

2-Bromobenzonitrile $(0.182 \mathrm{~g}, 1 \mathrm{mmol})$ and 2-n-propylthiazole $(0.254 \mathrm{~g}, 2 \mathrm{mmol})$ affords 38 in $76 \%(0.173 \mathrm{~g})$ yield. 


\section{5-Naphthalen-2-yl-2-propylthiazole (39) ${ }^{21}$}

2-Bromonaphthalene $(0.207 \mathrm{~g}, 1 \mathrm{mmol})$ and 2-n-propylthiazole $(0.254 \mathrm{~g}, 2 \mathrm{mmol})$ affords 39 in 78\% (0.197 g) yield.

\section{3-(2-Propylthiazol-5-yl)pyridine $(40)^{8 \mathrm{~d}}$}

3-Bromopyridine $(0.158 \mathrm{~g}, 1 \mathrm{mmol})$ and 2-n-propylthiazole $(0.254 \mathrm{~g}, 2 \mathrm{mmol})$ affords $\mathbf{4 0}$ in $84 \%(0.171 \mathrm{~g})$ yield.

\section{4-(2-Propylthiazol-5-yl)pyridine $(41)^{9 \mathrm{i}}$}

4-Bromopyridine hydrochloride $(0.194 \mathrm{~g}, 1 \mathrm{mmol})$ and 2-npropylthiazole $(0.254 \mathrm{~g}, 2 \mathrm{mmol})$ affords 41 in $85 \%(0.174 \mathrm{~g})$ yield.

\section{2-(2-Propylthiazol-5-yl)quinoline (42) $)^{8 \mathrm{~d}}$}

3-Bromoquinoline $(0.208 \mathrm{~g}, 1 \mathrm{mmol})$ and 2-n-propylthiazole $(0.254 \mathrm{~g}, 2 \mathrm{mmol})$ affords 42 in $86 \%(0.219 \mathrm{~g})$ yield.

\section{4-(2-Ethyl-4-methylthiazol-5-yl)benzaldehyde (43) ${ }^{8 a}$}

4-Bromobenzaldehyde (0.184 g, $1 \mathrm{mmol})$ and 2-ethyl-4methylthiazole $(0.254 \mathrm{~g}, 2 \mathrm{mmol})$ affords 43 in $80 \%(0.185 \mathrm{~g})$ yield.

\section{2-(2-Ethyl-4-methylthiazol-5-yl)benzonitrile $(44)^{8 \mathrm{~d}}$}

2-Bromobenzonitrile $(0.182 \mathrm{~g}, 1 \mathrm{mmol})$ and 2-ethyl-4methylthiazole $(0.254 \mathrm{~g}, 2 \mathrm{mmol})$ affords 44 in $87 \%(0.199 \mathrm{~g})$ yield.

\section{4-(2-Ethyl-4-methylthiazol-5-yl)-pyridine (45) ${ }^{8 \mathrm{~d}}$}

4-Bromopyridine hydrochloride $(0.194 \mathrm{~g}, 1 \mathrm{mmol})$ and 2-ethyl4-methylthiazole $(0.254 \mathrm{~g}, 2 \mathrm{mmol})$ affords 45 in 78\% (0.159 g) yield.

\section{4-(4-Methylthiazol-5-yl)-acetophenone (46) ${ }^{8 \mathrm{~d}}$}

4-Bromoacetophenone $(0.199 \mathrm{~g}, 1 \mathrm{mmol})$ and 4-methylthiazole $(0.198 \mathrm{~g}, 2 \mathrm{mmol})$ affords 46 in $80 \%(0.174 \mathrm{~g})$ yield.

\section{4-(4-Methylthiazol-5-yl)-benzonitrile (47) ${ }^{8 \mathrm{~d}}$}

4-Bromobenzonitrile $(0.182 \mathrm{~g}, 1 \mathrm{mmol})$ and 4-methylthiazole $(0.198 \mathrm{~g}, 2 \mathrm{mmol})$ affords $47 \mathrm{in} 81 \%(0.162 \mathrm{~g})$ yield.

\section{3-(4-Methylthiazol-5-yl)-acetophenone (48)}

3-Bromoacetophenone $(0.199 \mathrm{~g}, 1 \mathrm{mmol})$ and 4-methylthiazole $(0.198 \mathrm{~g}, 2 \mathrm{mmol})$ affords $\mathbf{4 8}$ in $73 \%(0.159 \mathrm{~g})$ yield.

\section{3-(4-Methylthiazol-5-yl)-quinoline (49)}

3-Bromoquinoline (0.208 $\mathrm{g}, 1 \mathrm{mmol})$ and 4-methylthiazole $(0.198 \mathrm{~g}, 2 \mathrm{mmol})$ affords 49 in $76 \%(0.172 \mathrm{~g})$ yield.

\section{tert-Butyl 5-phenylthiazole-4-carboxylate (50)}

Iodobenzene $(0.055 \mathrm{~g}, 0.35 \mathrm{mmol})$ and tert-butylthiazole-4carboxylate $^{8 \mathrm{c}}(0.027 \mathrm{~g}, 0.35 \mathrm{mmol})$ affords $\mathbf{5 0}$ in $53 \%(0.037 \mathrm{~g})$ yield.

\section{tert-Butyl 5-(4-cyanophenyl)-2-phenyl-thiazole-4-carboxylate} (51)

Iodobenzene $(0.110 \mathrm{~g}, \quad 0.70 \mathrm{mmol})$ and tert-butyl 5-(4cyanophenyl)thiazole-4-carboxylate ${ }^{22}(0.077 \mathrm{~g}, 0.35 \mathrm{mmol})$ affords 51 in 70\% (0.068 g) yield.

tert-Butyl 5-(4-methoxyphenyl)-2-phenyl-thiazole-4-carboxylate (52)

Iodobenzene $(0.110 \mathrm{~g}, \quad 0.70 \mathrm{mmol})$ and tert-butyl 5-(4methoxyphenyl)thiazole-4-carboxylate ${ }^{22}(0.079 \mathrm{~g}, 0.35 \mathrm{mmol})$ affords $\mathbf{5 2}$ in $83 \%(0.082 \mathrm{~g})$ yield.

\section{4-Benzothiazol-2-yl-benzaldehyde $(53)^{23}$}

4-Bromobenzaldehyde $(0.184 \mathrm{~g}, 1 \mathrm{mmol})$ and benzothiazole $(0.270 \mathrm{~g}, 2 \mathrm{mmol})$ affords 53 in $89 \%(0.213 \mathrm{~g})$ yield.

\section{2-Benzothiazol-2-yl-benzonitrile (54) ${ }^{24}$}

2-Bromobenzonitrile $(0.182 \mathrm{~g}, 1 \mathrm{mmol})$ and benzothiazole $(0.270 \mathrm{~g}, 2 \mathrm{mmol})$ affords 54 in $52 \%(0.123 \mathrm{~g})$ yield.

\section{2-n-Butyl-5-(4-acetylphenyl)furan (55) $)^{5 \mathrm{f}}$}

4-Bromoacetophenone $(0.199 \mathrm{~g}, 1 \mathrm{mmol})$ and 2-n-butylfuran $(0.248 \mathrm{~g}, 2 \mathrm{mmol})$ affords 55 in $70 \%(0.170 \mathrm{~g})$ yield.

\section{Methyl 4-(5-n-butyl-furan-2-yl)-benzoate (56)}

Methyl 4-bromobenzoate $(0.215 \mathrm{~g}, 1 \mathrm{mmol})$ and 2-n-butylfuran $(0.248 \mathrm{~g}, 2 \mathrm{mmol})$ affords 56 in $56 \%(0.145 \mathrm{~g})$ yield.

\section{2-n-Butyl-5-(4-cyanophenyl)furan $(57)^{5 b}$}

4-Bromobenzonitrile $(0.182 \mathrm{~g}, 1 \mathrm{mmol})$ and 2-n-butylfuran $(0.248 \mathrm{~g}, 2 \mathrm{mmol})$ affords 57 in $61 \%(0.137 \mathrm{~g})$ yield.

\section{2-n-Butyl-5-(3-formylphenyl)furan (58) ${ }^{5 b}$}

3-Bromobenzaldehyde $(0.184 \mathrm{~g}, 1 \mathrm{mmol})$ and 2-n-butylfuran $(0.248 \mathrm{~g}, 2 \mathrm{mmol})$ affords 58 in $62 \%(0.141 \mathrm{~g})$ yield.

\section{2-(5-n-Butylfuran-2-yl)benzonitrile (59) $)^{5 f}$}

2-Bromobenzonitrile $(0.182 \mathrm{~g}, 1 \mathrm{mmol})$ and 2-n-butylfuran $(0.248 \mathrm{~g}, 2 \mathrm{mmol})$ affords 59 in $84 \%(0.189 \mathrm{~g})$ yield.

\section{2-n-Butyl-5-(3-quinolyl)furan (60) ${ }^{5 b}$}

3-Bromoquinoline $(0.208 \mathrm{~g}, 1 \mathrm{mmol})$ and 2-n-butylfuran $(0.248 \mathrm{~g}, 2 \mathrm{mmol})$ affords 60 in $85 \%(0.213 \mathrm{~g})$ yield.

\section{4-(5-n-Butylthiophen-2-yl)acetophenone $(61)^{4 c}$}

4-Bromoacetophenone (0.199 g, $1 \mathrm{mmol})$ and 2-nbutylthiophene $(0.280 \mathrm{~g}, 2 \mathrm{mmol})$ affords 61 in $63 \%(0.163 \mathrm{~g})$ yield.

\section{4-(5-n-Butylthiophen-2-yl)benzonitrile (62) ${ }^{4 c}$}

4-Bromobenzonitrile $(0.182 \mathrm{~g}, 1 \mathrm{mmol})$ and 2-n-butylthiophene $(0.280 \mathrm{~g}, 2 \mathrm{mmol})$ affords 62 in $78 \%(0.188 \mathrm{~g})$ yield. 


\section{Methyl 4-(5-n-butylthiophen-2-yl)-benzoate (63) ${ }^{4 \mathrm{c}}$}

Methyl 4-bromobenzoate $(0.215 \mathrm{~g}, 1 \mathrm{mmol})$ and 2-nbutylthiophene $(0.280 \mathrm{~g}, 2 \mathrm{mmol})$ affords 63 in $46 \%(0.126 \mathrm{~g})$ yield.

\section{2-3,5-Bis(trifluoromethyl)phenyl-5-n-butylthiophene $(64)^{4 \mathrm{~h}}$}

3,5-Bis(trifluoromethyl)bromobenzene $(0.293 \mathrm{~g}, 1 \mathrm{mmol})$ and 2n-butylthiophene $(0.280 \mathrm{~g}, 2 \mathrm{mmol})$ affords 64 in $53 \%(0.187 \mathrm{~g})$ yield.

\section{2-(5-Butylthiophene-2-yl)benzonitrile (65) ${ }^{4 \mathrm{~h}}$}

2-Bromobenzonitrile $(0.182 \mathrm{~g}, 1 \mathrm{mmol})$ and 2-n-butylthiophene $(0.280 \mathrm{~g}, 2 \mathrm{mmol})$ affords 65 in $81 \%(0.195 \mathrm{~g})$ yield.

\section{3-(5-n-Butylthiophen-2-yl)pyridine (66) ${ }^{4 \mathrm{c}}$}

3-Bromopyridine $(0.158 \mathrm{~g}, 1 \mathrm{mmol})$ and 2-n-butylthiophene $(0.280 \mathrm{~g}, 2 \mathrm{mmol})$ affords 66 in $71 \%(0.154 \mathrm{~g})$ yield.

\section{4-(3,5-Dimethylisoxazol-4-yl)-acetophenone $(67)^{10}$}

4-Bromoacetophenone $(0.199 \mathrm{~g}, 1 \mathrm{mmol})$ and $3,5-$ dimethylisoxazole $(0.192 \mathrm{~g}, 2 \mathrm{mmol})$ affords 67 in $71 \%$ $(0.153 \mathrm{~g})$ yield.

\section{4-(3,5-Dimethylisoxazol-4-yl)-benzonitrile (68) ${ }^{25}$}

4-Bromobenzonitrile $(0.182 \mathrm{~g}, \quad 1 \mathrm{mmol})$ and $3,5-$ dimethylisoxazole $(0.192 \mathrm{~g}, 2 \mathrm{mmol})$ affords $\mathbf{6 8}$ in $47 \%$ $(0.093 \mathrm{~g})$ yield.

\section{2-(3,5-Dimethylisoxazol-4-yl)-benzonitrile (69) ${ }^{10}$}

2-Bromobenzonitrile $(0.182 \mathrm{~g}, \quad 1 \mathrm{mmol})$ and $3,5-$ dimethylisoxazole $(0.192 \mathrm{~g}, 2 \mathrm{mmol})$ affords 69 in $23 \%$ $(0.046 \mathrm{~g})$ yield.

\section{5-(4-Acetylphenyl)-1-methyl-2-formylpyrrole (70) ${ }^{\text {6e }}$}

4-Bromoacetophenone (0.199 g, $1 \mathrm{mmol})$ and 1-methyl-2formylpyrrole $(0.219 \mathrm{~g}, 2 \mathrm{mmol})$ affords 70 in $61 \%(0.139 \mathrm{~g})$ yield.

\section{4-(5-Formyl-1-methylpyrrol-2-yl)-benzonitrile (71) ${ }^{\text {e }}$}

4-Bromobenzonitrile $(0.182 \mathrm{~g}, 1 \mathrm{mmol})$ and 1-methyl-2formylpyrrole $(0.219 \mathrm{~g}, 2 \mathrm{mmol})$ affords 71 in $33 \%(0.069 \mathrm{~g})$ yield.

\section{5-(4-Formylphenyl)-1-methyl-2-formylpyrrole (72) ${ }^{6 \mathrm{e}}$}

4-Bromobenzaldehyde (0.184 g, $1 \mathrm{mmol})$ and 1-methyl-2formylpyrrole $(0.219 \mathrm{~g}, 2 \mathrm{mmol})$ affords 72 in $35 \%(0.075 \mathrm{~g})$ yield.

\section{5-(4-Acetylphenyl)-1,2-dimethylimidazole (73) $)^{7 \mathrm{f}}$}

4-Bromoacetophenone $(0.199 \mathrm{~g}, 1 \mathrm{mmol})$ and 1,2dimethylimidazole $(0.192 \mathrm{~g}, 2 \mathrm{mmol})$ affords 73 in $85 \%$ $(0.182 \mathrm{~g})$ yield.

\section{4-(2,3-Dimethylimidazol-4-yl)-benzonitrile (74) ${ }^{7 \mathrm{f}}$}

4-Bromobenzonitrile $(0.182 \mathrm{~g}, \quad 1 \mathrm{mmol})$ and $1,2-$ dimethylimidazole $(0.192 \mathrm{~g}, 2 \mathrm{mmol})$ affords 74 in $81 \%$ $(0.160 \mathrm{~g})$ yield.

\section{5-(4-Trifluoromethylphenyl)-1,2-dimethylimidazole (75) ${ }^{7 \mathrm{f}}$}

4-Trifluoromethylbromobenzene $(0.225 \mathrm{~g}, 1 \mathrm{mmol})$ and 1,2dimethylimidazole (0.192 g, 2 mmol) affords 75 in $48 \%(0.115 \mathrm{~g})$ yield.

\section{5-(3-Pyridyl)-1,2-dimethylimidazole (76) ${ }^{7 \mathrm{f}}$}

3-Bromopyridine $(0.158 \mathrm{~g}, 1 \mathrm{mmol})$ and 1,2-dimethylimidazole $(0.192 \mathrm{~g}, 2 \mathrm{mmol})$ affords 76 in 65\% (0.112 g) yield.

\section{Acknowledgements}

J. R. is grateful to "Ministère de la Recherche" for a grant. We thank the CNRS and "Rennes Metropole" for providing financial support and C. Fischmeister for helpful discussions.

\section{References}

1 (a) J. J. Li, G. W. Gribble, Palladium in Heterocyclic Chemistry, Pergamon: Amsterdam, 2000; (b) E. Negishi, Ed. Handbook of Organopalladium Chemistry for Organic SynthesisWiley-Interscience: New York, 2002, Part III, p. 213; (c) I. Kondolff, H. Doucet and M. Santelli, Synlett, 2005, 2057.

2 (a) Y. Akita, A. Inoue, K. Yamamoto and A. Ohta, Heterocycles, 1985, 23, 2327; (b) A. Ohta, Y. Akita, T. Ohkuwa, M. Chiba, R. Fukunaga, A. Miyafuji, T. Nakata, N. Tani and Y. Aoyagi, Heterocycles, 1990, 31, 1951; (c) Y. Aoyagi, A. Inoue, I. Koizumi, R. Hashimoto, K. Tokunaga, K. Gohma, J. Komatsu, K. Sekine, A. MiyafSuji, J. Kunoh, R. Honma, Y. Akita and A. Ohta, Heterocycles, 1992, 33, 257.

3 (a) D. Alberico, M. E. Scott and M. Lautens, Chem. Rev., 2007, 107, 174; (b) T. Satoh and M. Miura, Chem. Lett., 2007, 36, 200; (c) L.-C. Campeau, D. R. Stuart and K. Fagnou, Aldrichimica Acta, 2007, 40, 35; (d) I. V. Seregin and V. Gevoryan, Chem. Soc. Rev., 2007, 36, 1173; (e) B.-J. Li, S.-D. Yang and Z.-J. Shi, Synlett, 2008, 949; (f) F. Bellina and R. Rossi, Tetrahedron, 2009, 65, 10269; $(g)$ L. Ackermann, R. Vincente and A. R. Kapdi, Angew. Chem., Int. Ed., 2009, 48, 9792; (h) J. Roger, A. L. Gottumukkala and H. Doucet, ChemCatChem, 2010, 2, 20; (i) D. Roy, S. Mom, M. Beaupérin, H. Doucet and J.-C. Hierso, Angew. Chem., Int. Ed., 2010, 49, 6650.

4 For recent examples of direct arylations of thiophenes: (a) E. David, S. Pellet-Rostaing and M. Lemaire, Tetrahedron, 2007, 63, 8999; (b) H. A. Chiong and O. Daugulis, Org. Lett., 2007, 9, 1449; (c) A. Battace, M. Lemhadri, T. Zair, H. Doucet and M. Santelli, $A d v$. Synth. Catal., 2007, 349, 2507; (d) P. Amaladass, J. A. Clement and A. K. Mohanakrishnan, Tetrahedron, 2007, 63, 10363; (e) F. Derridj, A. L. Gottumukkala, S. Djebbar and H. Doucet, Eur. J. Inorg. Chem., 2008, 2550; $(f)$ M. Nakano, H. Tsurugi, T. Satoh and M. Miura, Org. Lett., 2008, 10, 1851; $(g)$ J. J. Dong, J. Roger and H. Doucet, Tetrahedron Lett., 2009, 50, 2778; (h) J. Roger, F. Požgan and H. Doucet, Green Chem., 2009, 11, 425; (i) B. Liégault, I. Petrov, S. I. Gorlesky and K. Fagnou, J. Org. Chem., 2010, 75, 1047; (j) J. Roger and H. Doucet, Eur. J. Org. Chem., 2010, 4412.

5 For recent examples of direct arylations of furans: (a) M. Parisien, D. Valette and K. Fagnou, J. Org. Chem., 2005, 70, 7578; (b) A. Battace, M. Lemhadri, T. Zair, H. Doucet and M. Santelli, Organometallics, 2007, 26, 472; (c) E. M. Beccalli, G. Broggini, M. Martinelli and S. Sottocornola, Synthesis, 2008, 136; (d) A. L. Gottumukkala and H. Doucet, Adv. Synth. Catal., 2008, 350, 2183; (e) B. Liégaut, D. Lapointe, L. Caron, A. Vlassova and K. Fagnou, J. Org. Chem., 2009, 74, 1826; $(f)$ J. J. Dong, J. Roger, F. Požgan and H. Doucet, Green Chem., 2009, 11, 1832; (g) M. Ionita, J. Roger and H. Doucet, ChemSusChem, 2010, 3, 367. 
6 For recent examples of direct arylations of pyrroles or indoles: $(a) \mathrm{F}$. Bellina, S. Cauteruccio and R. Rossi, Eur. J. Org. Chem., 2006, 1379; (b) X. Wang, D. V. Gribkov and D. Sames, J. Org. Chem., 2007, 72, 1476; (c) N. Lebrasseur and I. Larrosa, J. Am. Chem. Soc., 2008, 130, 2926; (d) Y. Fall, H. Doucet and M. Santelli, ChemSusChem, 2009, 2, 153; (e) J. Roger, F. Pozgan and H. Doucet, Adv. Synth. Catal., 2010, 352, 696.

7 For recent examples of direct arylations of imidazoles: (a) F. Bellina, S. Cauteruccio, L. Mannina, R. Rossi and S. Viel, Eur. J. Org. Chem., 2006, 693; (b) I. Cerna, R. Pohl, B. Klepetarova and M. Hocek, Org. Lett., 2006, 8, 5389; (c) F. Bellina, C. Calandri, S. Cauteruccio and R. Rossi, Tetrahedron, 2007, 63, 1970; (d) F. Bellina, S. Cauteruccio, A. Di Flore and R. Rossi, Eur. J. Org. Chem., 2008, 5436; (e) F. Bellina, S. Cauteruccio, A. Di Flore, C. Marchietti and R. Rossi, Tetrahedron, 2008, 64, 6060; (f) J. Roger and H. Doucet, Tetrahedron, 2009, 65, 9772.

8 For recent examples of direct 2- or 5-arylations of thiazoles: $(a)$ A. L. Gottumukkala and H. Doucet, Eur. J. Inorg. Chem., 2007, 3629; (b) L.-C. Campeau, M. Bertrand-Laperle, J.-P. Leclerc, E. Villemure, S. Gorelsky and K. Fagnou, J. Am. Chem. Soc., 2008, 130, 3276; (c) T. Martin, C. Verrier, C. Hoarau and F. Marsais, Org. Lett., 2008, 10, 2909; (d) J. Roger, F. Požgan and H. Doucet, J. Org. Chem., 2009, 74, 1179.

9 For recent examples of direct 2-arylations or vinylations of oxazoles: (a) C. Hoarau, A. Du Fou de Kerdaniel, N. Bracq, P. Grandclaudon, A. Couture and F. Marsais, Tetrahedron Lett., 2005, 46, 8573; (b) F. Bellina, S. Cauteruccio and R. Rossi, Eur. J. Org. Chem., 2006, 1379; (c) H. A. Chiong and O. Daugulis, Org. Lett., 2007, 9, 1449; (d) R. S. Sanchez and F. A. Zhuravlev, J. Am. Chem. Soc., 2007, 129, 5824; (e) F. Derridj, S. Djebbar, O. Benali-Baitich and H. Doucet, J. Organomet. Chem., 2008, 693, 135; $(f)$ F. Besselievre, F. MahuteauBetzer, D. S. Grierson and S. Piguel, J. Org. Chem., 2008, 73, 3278; (g) C. Verrier, T. Martin, C. Hoarau and F. Marsais, J. Org. Chem., 2008, 73, 7383; (h) T. Yoshizumi, T. Satoh, K. Hirano, D. Matsuo, A. Orita, J. Otera and M. Miura, Tetrahedron Lett., 2009, 50, 3273; (i) F. Derridj, J. Roger, S. Djebbar and H. Doucet, J. Organomet. Chem., 2009, 694, 455; (j) C. Verrier, C. Hoarau and F. Marsais, Org. Biomol. Chem., 2009, 7, 647; (k) F. Besselievre, S. Lebrequier, F. Mahuteau-Betzer and S. Piguel, Synthesis, 2009, 3511.

10 For recent examples of direct arylations of isoxazoles: Y. Fall, C. Reynaud, H. Doucet and M. Santelli, Eur. J. Org. Chem., 2009, 4041.

11 (a) G. L. Turner, J. A. Morris and M. F. Greaney, Angew. Chem., Int. Ed., 2007, 46, 7996; (b) S. A. Ohnmacht, P. Mamone, A. J. Culshaw and M. F. Greaney, Chem. Commun., 2008, 1241; (c) S. A. Ohnmacht, A. J. Culshaw and M. F. Greaney, Org. Lett., 2010, 12, 224.

12 O. René and K. Fagnou, Org. Lett., 2010, 12, 2116.

13 L. Ackermann and R. Vicente, Org. Lett., 2009, 11, 4922.

14 (a) P. Tundo and M. Selva, Acc. Chem. Res., 2002, 35, 706; (b) T. Sakakura and K. Kohno, Chem. Commun., 2009, 1312; (c) B. Schäffner, F. Schäffner, S. P. Verevkin and A. Börner, Chem. Rev, 2010, 111, 4554; (d) P. T. Anastas, W. Leitner, P. G. Jessop, C. J. Li, P. Wasserscheid, A. Stark, Handbook of Green Chemistry - Green Solvents, Wiley-VCH, Weinheim, 2010.

15 (a) M. T. Reetz and G. Lohmer, Chem. Commun., 1996, 1921; (b) G. Vasapollo, G. Mele, A. Maffei and R. Del Sole, Appl. Organomet. Chem., 2003, 17, 835; (c) J. Bayardon, J. Holz, B. Schäffner, V. Andrushko, S. Verevkin, A. Preetz and A. Börner, Angew. Chem., Int. Ed., 2007, 46, 5971; (d) X. Miao, C. Fischmeister, C. Bruneau and P. H. Dixneuf, ChemSusChem, 2008, 1, 813; (e) B. Schäffner, J. Holz, S. P. Verevkin and A. Börner, ChemSusChem, 2008, 1, 249; (f) V R. Bernini, E. Mincione, M. Barontini, F. Crisante, G. Fabrizi and A. Gambacorta, Tetrahedron, 2007, 63, 6895; $(g)$ J. Cornely, L. M. Su Ham, D. E. Meade and V. Dragojlovic, Green Chem., 2003, 5, 34; $(h)$ C. Torborg, J. Huang, T. Schulz, B. Schäffner, A. Zapf, A. Spannenberg, A. Börner and M. Beller, Chem.-Eur. J., 2009, 15, 1329; (i) T. Schulz, C. Torborg, B. Schäffner, J. Huang, A. Zapf, R. Kadyrov, A. Börner and M. Beller, Angew. Chem., Int. Ed., 2009, 48, 918; (j) B. Schäffner, V. Andrushko, J. Bayardon, J. Holz and A. Börner, Chirality, 2009, 21, 857.

16 P. Arockiam, V. Poirier, C. Fischmeister, C. Bruneau and P. H. Dixneuf, Green Chem., 2009, 11, 1871.

17 For preliminary results see: J. Roger, C. Verrier, R. Le Goff, C. Hoarau and H. Doucet, ChemSusChem, 2009, 2, 951.

18 K.-W Henneke, U. Schöllkopf and T. Neudecker, Liebigs Ann. Chem., 1979, 1370.

19 T. Cantat, E. Génin, C. Giroud, G. Meyer and A. Jutand, J. Organomet. Chem., 2003, 687, 365.

20 D. A. Thomas, J. Heterocycl. Chem., 1970, 7, 457.

21 J. Roger and H. Doucet, Org. Biomol. Chem., 2008, 6, 169.

22 W. Gassner, R. Imhof and E. Kyburz, Eur. Pat. Appl., EP 352581A2, 1990.

23 K. Bahrami, M. M. Khodaei and F. Naali, J. Org. Chem., 2008, 73, 6835.

24 P. J. Palmer, G. Hall, R. B. Trigg and J. V. Warrington, J. Med. Chem., 1971, 14, 1223.

25 G. A. Molander, B. Canturk and L. E. Kennedy, J. Org. Chem., 2009, 74, 973 . 